\title{
Bach meets the Boogie Kings
}

\author{
By Laura Dankner \\ Music Librarian \\ Loyola University, New Orleans
}

\section{Peaceful coexistence among disparate musical styles in an academic music library.}

$\mathbf{T}_{\mathrm{s}}$ his paper originally opened with an eloquent plea justifying the place of Boogie in a world where Bach, not Elvis, is King. But who was it who said, "Don't preach to the converted"? In place of a sermon, imagine you are at a New Orleans bar called Tipitina's, sipping a Dixie longneck and listening to "Big Chief" by Professor Longhair on the jukebox. This is a prime example of the basic New Orleans piano sound that Longhair pioneered beginning in the 1940s and that is part of Loyola's Louisiana Music Collection, the largest segment of all our popular music holdings.

The Music Library is the only branch library at Loyola, which has an enrollment of 5,000 students. We are small, with under 40,000 books, scores, recordings, periodicals, and microforms, but we offer a full array of academic library services to all members of the university community, although we are physically located within the College of $\mathrm{Mu}$ sic. But the 225 music majors and College of Music faculty are our heaviest users. The music portion of the library acquisitions budget, of which I am in charge, is used to buy curriculum-related materials; and the curriculum at Loyola, with the exception of our strong jazz program, heavily emphasizes Western art music.

So you might say we have a garden variety academic music library. And to be honest, I am a garden variety academic music librarian, with roots firmly planted in classical music. So what's a nice long-hair librarian-type like me doing in a world of Fats Domino, anyway?
Certainly no child of the Sixties could have escaped being influenced by popular music. In fact, I know I am getting old when I grumpily tell students that "our" music (like the Beatles, since I conveniently forget about the bad stuff) is better than "their" music. But when I first moved to New Orleans, I knew virtually nothing about Louisiana's rich musical heritage. Dixieland and Louis Armstrong - that was about the extent of my knowledge.

However, I quickly discovered that the local music scene was incredibly varied and culturally diverse. Since I am a child of the Sixties, it isn't surprising that New Orleans 1960s rhythm and blues was the first local music that really grabbed me. During the so-called Golden Age of New Orleans music, many songs, such as Jesse Hill's “Ooh Poo Pah Doo," made the national R\&B charts.

Over the years I came to love them all-1960s rhythm and blues, 1970s funk, swamp pop, rockabilly from the Texas border, contemporary free jazz, soul, gospel, punk, and an infinite variety of combinations. Cajun music and Cajun food have both become amazingly popular very recently. Most Cajun songs are sung in a French dialect, such as "Zydeco Gris Gris" (heard in the movie "The Big Easy") by Beausoleil, an innovative Cajun band from Lafayette.

If you are familiar with Louisiana music, perhaps you can see (or hear) why I was converted. I thought this wonderful stuff belonged in my library. I also wanted to introduce our users to a 


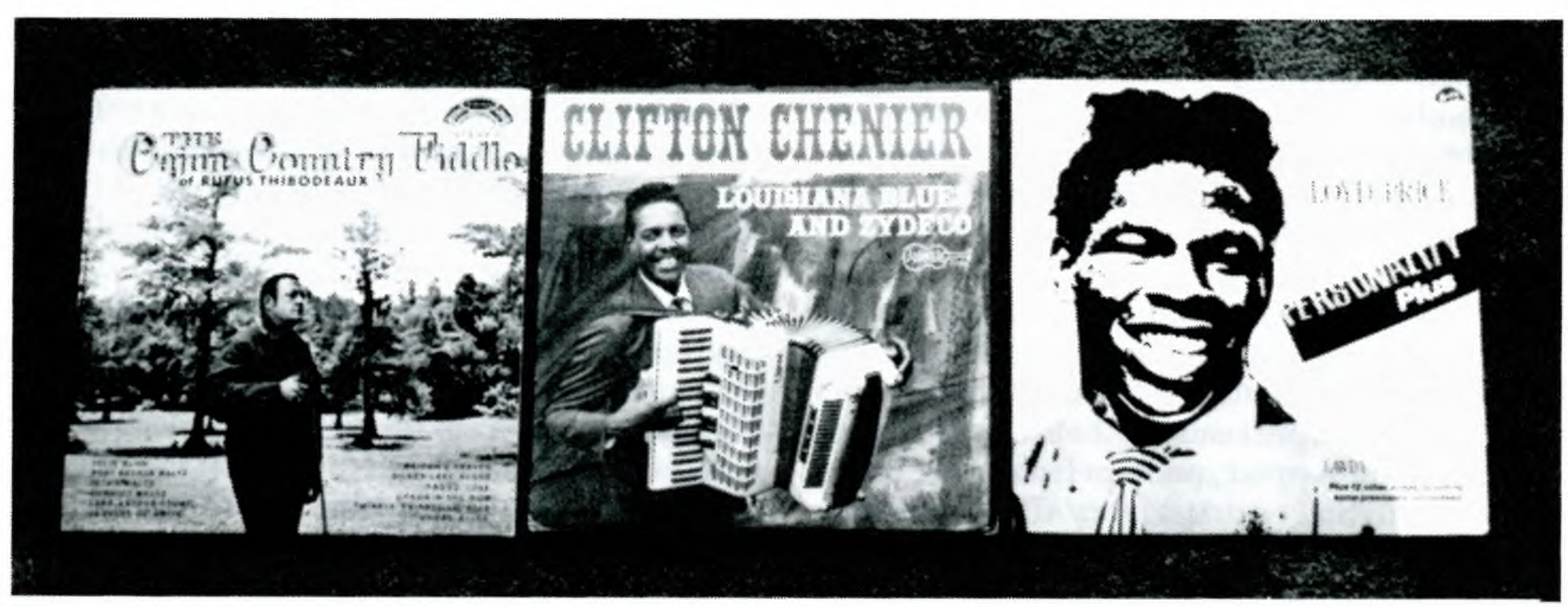

Louisiana musicians offer a wide variety of genres. Left to right: Rufus Thibodeaux (Cajun), Clifton Chenier (zydeco), Lloyd Price (RむB).

broader palette, so I actually had two goals in mind: 1) to include both Louisiana and more mainstream popular music styles in a new popular record collection; and 2) to place this music with all our other records, on the open shelves in the Music Library, since in no way did I want this to be considered a special collection, in the upper-case, restricted-access meaning of the term.

But I had no way to justify spending a lot of money on popular music. My modest budget simply wasn't earmarked for the likes of Bruce Springsteen or Beausoleil. It was intended to buy materials supporting the music curriculum, and very few classes even acknowledged the existence of popular music. Was this going to be a realistic project?

First I made sure there really was a need for us to collect popular music. The answer, after an informal survey of several local academic and public libraries, was an emphatic yes. In fact, Louisiana music, with the exception of traditional Dixieland jazz, was surprisingly under-represented in nearly all the institutions I surveyed.

I decided that I would use a modest sum from my regular music budget to purchase the mainstream, nationally known pop music genres, and to look elsewhere for funding the Louisiana portion of the project. This was based on my feeling that, although it's one thing to rationalize the place of Bob Dylan in an academic music library, it is much harder to defend the literary or sociological value of "Ooh Poo Pah Doo." I did not feel that it was either politically or ethically supportable to use regular funding sources on music, however delightful, that was unrelated to any course offerings at Loyola. Separate funding seemed the best solution.

While the first recordings of non-local music were bought with money from the Music Library allocation, in succeeding years an additional funding source was discovered. At Loyola the library acquisitions budget, although officially one lump sum, is divided into several budget lines. The line dedicated to music library acquisitions had to be used to support purchases related to the College of Music, but there was another funding source that might be tapped as well. This was the allocation set aside for City College, as the university's evening division is known. On the faculty of City College is an instructor who teaches music appreciation courses to evening students. Popular music is an important component of these classes, and it seemed logical to discuss our project with both this instructor and the collections development librarian, who has jurisdiction over most budget lines with a few exceptions such as the Music Library funds.

Both seemed enthusiastic about my proposal and agreed that it was appropriate to set aside a small portion of the City College budget line for popular music purchases to be housed in the Music Library. This agreement remained in effect for several years, significantly increasing our holdings of recordings, scores (especially "fake books," anthologies of popular songs), and books.

For the non-local purchases I found that the availability of many excellent retrospective anthologies made it possible to acquire a reasonably good overview of many different styles for a surprisingly small amount of money. Multi-volume sets issued

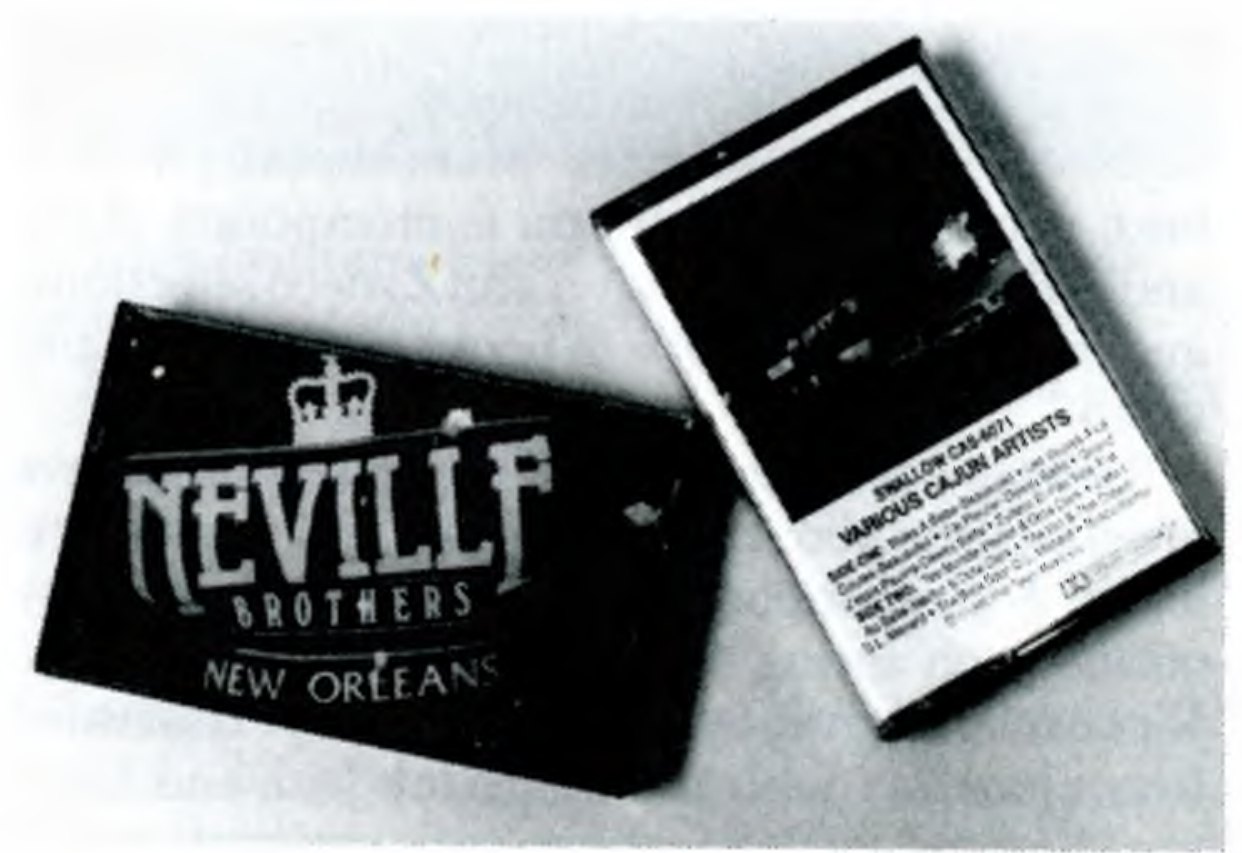

The Neville Brothers, live at Tipitina's; and Cajun musicians, live at Mulate's. 
by Motown, Atlantic, the Smithsonian, Time-Life, and others became the backbone of our popular music holdings. Unfortunately our budget restraints made it impractical to go much beyond the anthology approach, but at least we had a basic, though limited, collection of the major styles and artists.

As I mentioned earlier, I had determined that funding for the Louisiana portion of the new collection had to be found outside our normal channels. At first I simply assumed that I would have to apply for grant support, perhaps from a local or regional foundation or arts agency. But before embarking on the always time-consuming and often disappointing grantsmanship route, I thought that it wouldn't hurt to see what my colleague in the Main Library, the collections development librarian, had to suggest. To my delight, he offered to let us have a special allocation from the library's general fund that would be earmarked for the purchase of Louisiana popular music recordings. This special award enabled us to purchase the first and largest group of Louisiana recordings immediately. I will always be grateful to both the collections librarian and the university librarian (who ultimately must approve all acquisitions spending requests) for their support and encouragement.

With funding for the first round of Louisiana recordings in hand, I decided that our first priority would be New Orleans rhythm and blues: Fats Domino, Dave Bartholomew, and Allen Toussaint were among those writers and performers who came into prominence from the late 1950s to the mid-1960s. The later 1960s and 1970s, heyday of Dr. John the Nighttripper and The Meters (a funk band), would also be emphasized. Finally we attempted to collect all current, original albums of Louisiana performers throughout the state, regardless of style. The ever-practical retrospective anthology approach I had used earlier proved to be a budget-stretcher during this second phase of the project as well-especially practical for purchasing a good sampling of those New Orleans rhythm and blues performances.

Perhaps the most popular New Orleans group in the 1980s is the Neville Brothers, whose individual careers span three decades of New Orleans music. Their distinctive funk-influenced rhythm is well represented in anthologies. More recently I have been concentrating more on contemporary styles and artists, especially Cajun and Zydeco selections, and expanding our scope to books, periodicals, and video.

To keep our users aware of the collection, I have often written about it in the Music Library's newsletter. A great opportunity for additional publicity occurs each spring when we prepare our annual Jazz Fest discography and bibliography. It is issued in conjunction with the Louisiana Jazz and Heritage Festival, which features both national and local performers from Fats Domino and Miles Davis to Los Lobos. We also mount a small Jazz Fest ex- hibit, featuring articles from our books and magazines, photos of performers, and album covers.

I have also prepared a guide to various sources of information on Louisiana music and musicians. Although originally intended for the use of Loyola students, it was later published in a regional newsletter of the Music Library Association. I decided this year to expand the scope of this annotated bibliography, so that a fuller range of materials, even some not available at Loyola, could be included. A National Endowment for the Humanities Travel to Collections grant enabled me to visit the music library and sound recording archive at Bowling Green State University where I found many additional citations.

The recordings of local and national music have proven popular among our users, for both teaching and leisure-listening purposes. In fact, we have had to limit our compact disk circulation policies largely due to the popularity of the Beatles on CD, which patrons complained were always checked out. Immensely popular during the Mardi Gras season is our Carnival music, rarely played anywhere else except in Louisiana for a few weeks in February or March. Our contemporary Louisiana jazz recordings are used a lot, especially those featuring the various members of the Grammygrabbing Marsalis clan. I also answer a number of reference questions, especially about Louisiana music, from both inside and outside the university; and our non-reference books about popular music circulate frequently, both at Loyola and through interlibrary loan.

Our upswing in circulation statistics, due in some part to the popular music collection, is persuasive at budget allocation time. The library administration is also impressed that the collection is slowly becoming known outside the university, because community outreach is actively encouraged at Loyola.

One of the most satisfying benefits has been the positive response from people who aren't our usual patrons. They include students, faculty and staff who are not affiliated with the College of Music as well as people from outside the university. Once they have discovered that we have this kind of music their visits are more frequent and they sometimes discover our much larger holdings of classical music in the process. The reverse is also true for music majors studying Western art music who come to appreciate popular music for the first time. When such interaction takes place, it really does become a case of Bach meets the Boogie Kings, rather than Bach versus the Boogie Kings!

In case you were wondering, the Boogie Kings are indeed a Louisiana group, although I must admit I chose their name because it goes well with Bach. In yet another permutation of Louisiana music, the Boogie Kings are a white soul group who have produced an almost exact cover of a New Orleans R\&B classic hit, Aaron Neville's "Tell It Like It Is." 
As you can see, my enthusiasm for the place of popular music in an academic setting is high. That does not mean there are no pitfalls, including the very real problem of protecting the collection from theft. This is crucial when you are dealing with a non-research collection like ours with materials readily accessible and therefore stealable. CDs are especially vulnerable.

And we have had other problems, such as finding the funds to keep the project going. Unfortunately the Main Library is no longer able to allocate special grants or allow us to utilize non-music budget lines. Since the Music Library budget must continue to be earmarked for curriculum-related purchases, we have for the first time applied for grant money to purchase additional popular and local music materials. I am exploring other options as well and feel confident that we will be able to continue adding to the existing collection.

The popular music collection has indeed turned out to complement and not compete with the curriculum-oriented materials in our library. Knowing the limitations, being aware of the primary mission of the university, and remaining sensitive to the politics and economics of the situation makes integrating popular music into our collection feasible and rewarding.

So if you are planning to be in New Orleans this July for the ALA Annual Conference, take the St. Charles streetcar uptown (a tourist "must" in any case) and come visit us at the Loyola Music Library. You are welcome to use our collection, whether you're interested in Bach, the Boogie Kings or-better yet-both!

Editor's note: This article is based on a paper presented at the Annual Meeting of the Popular Culture Association in New Orleans, March 25, 1988.

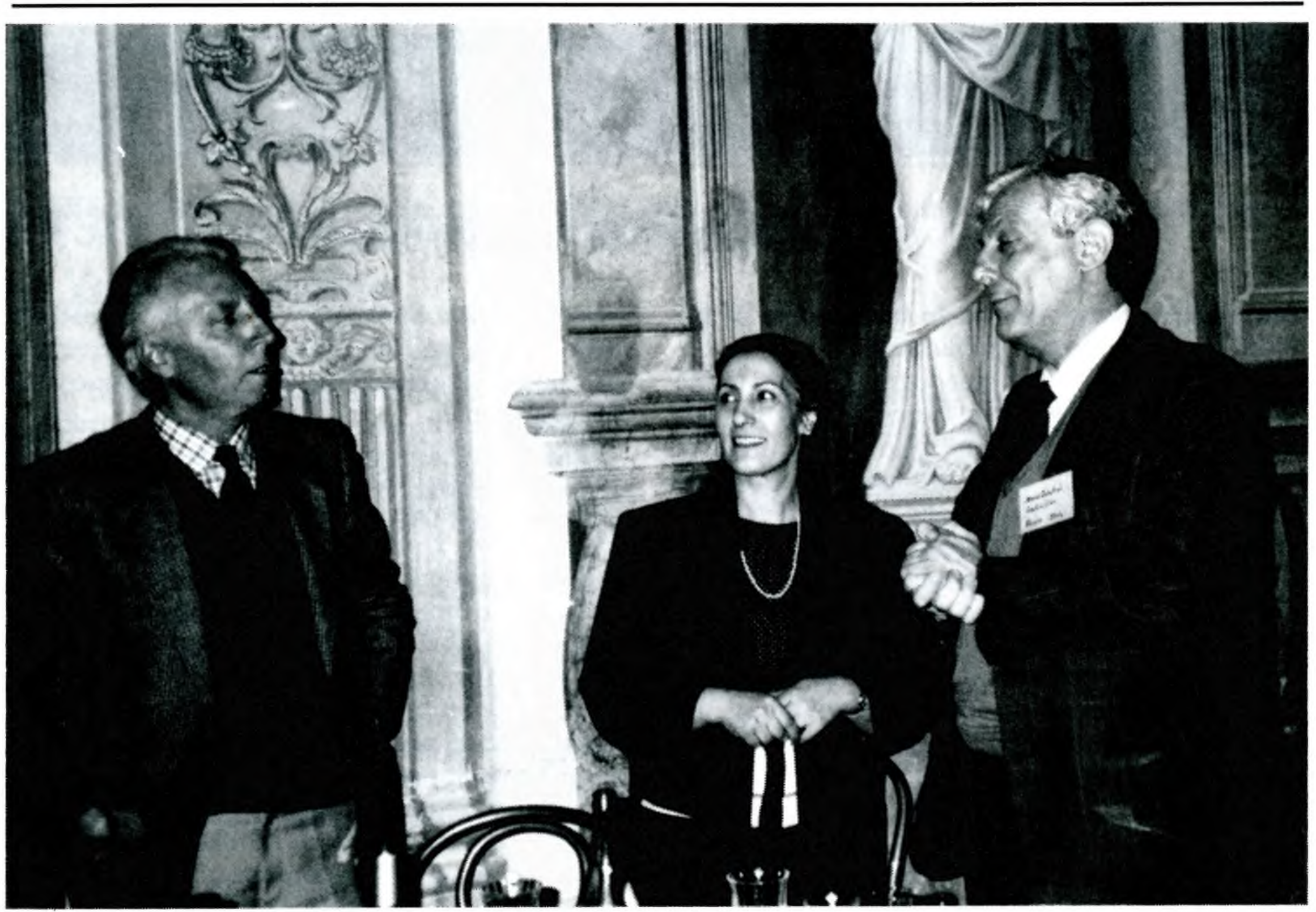

(l-r) Marcello Buzzonetti, Secretary, European University Institute, Fiesole, Italy; Assunta Pisani, Collection Development Librarian, Harvard University; and Mario Casalini Managing Director,

Casalini Libri, Fiesole.

Credit: Martha Brogan

\section{WESS goes to Florence}

To the second international conference of ACRL's Western European Specialists Section, held in Florence, Italy, on April 4-8, 1988, came 90 U.S. librarians to meet with 60 Western European librarians, publishers, and book distributors.
The aim of the conference, entitled "Shared Resources, Shared Responsibilities," was to enable these people to meet with each other and to discuss current collection development realities, trends and problems. One particular emphasis for Ameri- 